\title{
Whiteness Studies and the Colonial Aesthetic: West- ern Popular Culture and the Representations of Race
}

\author{
Isabel Cserno \\ University of Maryland, College Park
}

\begin{abstract}
As I have said before, planters are not poetical; but, my heart! if I possessed this place, methinks while young morning blushed, or high noon slept, or gentle dewy evening made nature think and pause, I would stroll upon my terrace, or sit, three parts recumbent, on one of those old oak chairs with Hasting's coronet on it, and forget the world of strife and penury and pain, till I lapsed into a citizen of the other world of peace and plenty and joy! Henry Nelson Coleridge, 1825
\end{abstract}

The study of "whiteness," as equally as racialized a category as "blackness," has generated a number of anthologies, monographs, and other publications in the past decades, culminating in a field often referred to as Critical Whiteness or White Studies. The commonality in all these publications is a concern to understand the role of "whiteness" as a racialized and ethnic category equal to "black" or African American, Latina/o, American Indian, Asian American, et al. Whiteness Studies explores the social, cultural, and political privileges of whiteness in a world dominated by Western markets and politics over the past centuries. The academic movement of Whiteness Studies materialized in the decades post-World War II and has since trickled into mainstream popular culture. In the past year, for example, the FX Network series Black \& White has pointed out 
not only the existing racism that people of color are exposed to on a daily basis, but the multiple racial privileges of whiteness. As the title suggests, the series narrates the experience of two families, one White American, the other African American, who are transformed into members of the opposite racial group. The simultaneous exploration of racial oppression and privilege highlights the fact that the social constructions of opposing racial and ethnic categories are interdependent. Drawing on Ethnic Studies, focusing on racially and ethnically marginalized groups, and Whiteness Studies, analyzing the materialization of white privilege, simultaneously, this article analyzes selected representations of colonial, imperial, and exotic landscapes and subjects in Western popular culture. With this analysis, I wish to demonstrate that Whiteness Studies can be an important element of an Ethnic Studies methodology. Through an exploration of material and visual culture artifacts, I wish to demonstrate the benefit of reading visual culture as an area where racial and ethnic meaning is produced and disseminated. The surviving legacy of exotized imagery in popular culture casts white and nonwhite groups in relationships that are controlled by century-long dynamics of discrimination, prejudice, and privilege based on constructions of racial and ethnic hierarchies. Casting Whiteness Studies as an integral part of Ethnic Studies inquiry is an important project to understand the complex dynamics of race and ethnicity in cultural representations, social structures, and cultural production, particularly for the study of popular culture.

Drawing on Ethnic Studies and Critical Whiteness Studies scholarship, the following analysis is based on the premise that the legacy of European colonialism created a colonial aesthetics that has survived in numerous expressions of Western popular cultures. In order to "study the cultural realities of [ethnic and racialized groups in the US], their relation to the body politic, and their unassimilated status because of racism and ethnocentrism intertwined with sexism, heterosexism, and classism, as well as religious, age, and physical ability discrimination", as Johnella Butler describes the task of Ethnic Studies, understanding the legacy of visual representations is essential. The depiction of colonial encounters, often uncritically reproduced in popular culture, firmly engraves the superiority of whiteness in Western ideologies and popular beliefs. Considering that we live in a "global village" grown out of colonial encounters, questions about the impact of colonialism's visual tropes and material environments on contemporary cultural expressions deserve our attention. Notwithstanding their intent, contemporary images, relying on colonial aesthetics, bear witness to century-long echoes of colonial exploitation and denigration of non-Westerners.

Often, the material and visual world as well as the realm of representations, although acknowledged by scholars in the social sciences and humanities, is subsumed by or incorporated into a wider conversation about social structures. 
Until recently, a systematic examination of popular culture and its visual and material manifestations has been absent in most Ethnic Studies scholarship, which has grown out of the social sciences with a natural concentration on non-visual source material. Although the theories of sociology, anthropology, psychology, and other related fields have created a conceptual language and practice for understanding social structures, identity formations, and cultural practices, the study of popular culture deserves to play a pivotal role in Ethnic Studies. Popular culture, and in particular visual and material culture, represent important areas of cultural formation. They contribute to the dissemination and creation of belief systems, identity formations, and social structures. As film scholar Richard Dyer reminds us in his seminal work White, "[t]he study of representations is more limited than the study of reality and yet it is also the study of one of the prime means by which we have any knowledge of reality."

Despite these limitations inherent in the world of representations, this article, through a close reading of selected visual material, wishes to invite a conversation among Ethnic Studies and Whiteness Studies about the surviving legacies of exoticized imagery. This imagery is saturated with overt explicit racial or ethnic references as well as with indistinct and underlying references to cultural constructions of racial otherness and privilege. These surviving legacies have become explicit marketing tools for a variety of merchandise such as chocolate products, drawing on colonial and imperial landscapes with century-long histories in Western popular culture. The article connects contemporary neo-colonial imagery in artwork, product packages, and material artifacts of day-to-day life with a century-long history of Western perceptions of tropical sceneries, nonwhite populations, and landscapes of luxury and indulgence. These artifacts and images offer a window into Western constructions of individuality and their dependence on racial and ethnic categories and hierarchies. According to Pieterse in White on Black, an extensive and unparalled study of racialized imagery in Western popular culture, "[we need to ask] who are the producers, and consumers of these images, and only then to question who are the objects or representations. The key that unlocks these images is what whites have made of blacks and why." Cultural representations in visual and material culture tell important stories about how (white) people have and still are imagining complex relationships between various cultural and racial or ethnic groups. They reveal how whites picture relationships among each other as well as with other non-white groups. To summarize, Ethnic and Whiteness studies can take on the critical task to uncover and detangle the complexities of racialized white identities and their interdependence on representations of non-whites. Together, they can scrutinize social and cultural structures, of which visual representations form a critical part, about their continuous dependence on the white-non white binary that gives meaning to most 
Western cultural formations.

\section{Colonial Aesthetic: "Imperial Kitsch" and "Tropical Plenty"}

The development of a colonial aesthetics was instrumental in Western cultures' experiences of colonial landscapes and subjects as well as of themselves. Anne McClintock discusses various manifestations of racism during British colonialism in her influential monograph Imperial Leather: Race, Gender and Sexuality in the Colonial Contest. She points to the racial attitudes and prejudices in nineteenth century consumer spectacles. Advertising culture, as she continues, had been a main site for the manifestation of organized racism: "Imperial kitsch as consumer spectacle [...] could package, market and distribute evolutionary racism on a hitherto unimaginable scale. No preexisting form of organized racism had been able to reach to reach so large and so differentiated a mass of the populace."

The images in nineteenth century advertising that McClintock describes as "imperial kitsch" drew on recognizable tropes of exoticism and otherness. Images and descriptions of exotic landscapes with abundant natural resources, farms or plantations nestled into these lush panoramas, were widely used in travel narratives, natural history texts, paintings, lithographs, illustrations and other published accounts starting in the sixteenth century. In the epitaph at the beginning of the article, Coleridge, in his 1825 travel narrative Six Months in the West Indies, expressed common awe and admiration for the panoramas of colonized territories" the other world of peace and plenty and joy" here referring specifically to the subtropical landscape of the Caribbean island Dominica located in the Lesser Antilles. By the late nineteenth century, these visual and textual representations of colonial sceneries had become common motifs in a variety of popular culture forms of Western nations. Advertising for items that bore a connection to production sites in the tropics and subtropics, such as cocoa, was full of these themes, as large-scale industrialization enabled mass production and mass distribution of items such as chocolate and coffee formerly restricted to smaller markets. Even contemporary consumer culture produces imagery of untouched, pristine landscapes, in which exotic merchandise full with nature's riches and tropical delights originate.

The connection of these exotic landscapes with black slave labor is not only reinforced in textual passage from various travel narratives, but also in the visual evidence that many of these texts supply. In John Augustine Waller's text from1820, A Voyage in the West Indies, several illustrations represent different aspects of his travels. One illustration in particular connects the exotic landscapes, black labor, and the enabling of white leisure by black servitude. Entitled 
"A Spanish Planter of PortoRico luxuriating in his hammock", the planter sits in the hammock while being served by one of his black slaves. The slave seems to carry a beverage of some kind, maybe coffee, maybe tea, that he is extending to his master. Non-whites cast as servants or slaves were naturally common elements in depicting colonial or imperial scenes and became a standard way or representations for non-whites: "Personal service by natives forms an essential component of the colonial ambience which is also psychologically satisfying." The simultaneous inscription of white superiority and non-white inferiority strengthened the racial hierarchies of colonial nations and created a visual legacy that affects visual representations of non-Western locations to this day.

Tropical landscapes such as the plantation scenery in Waller's illustration, or Coleridge's "other world of peace and plenty and joy," became associated with peacefulness, luxury, and comfort. This "imperial kitsch" or, as Pieterse calls it, images of "tropical plenty" carried messages of racialized hierarchies that supported the privileges of whites and the domination of non-whites. Similar to the illustration in Waller's text, the visual and textual elements in material and visual culture artifacts as well as textual descriptions often placed non-Western, non-white subjects as the enablers of this luxurious world, cast into roles of servants and laborers, inferior to the portrayed symbols of Western, white subjecticity. These symbols could range from actual representation of whites themselves, usually in positions superior to depicted natives, or inanimate objects, representing Western cultures such as factories or other technological machinery.

In contemporary Western cultures, the constructions of whiteness still play an important role in normalizing white identities and in marginalizing people of color. Despite commercial culture's use of apparent multicultural motives, often via a conglomeration of black, brown, yellow, red, white, and multiracial models, such as advertising campaigns for the Italian fashion mogul Benetton or U.S. companies like Tommy Hilfiger, these images remain one-dimensional and obscure the realities of economic, political, and social inequities based on ethnic and racial difference. Remnants of "imperial kitsch" and visions of" "tropical plenty" are rampant in visual representations of popular culture. The subtexts of luxury tied to a system of colonial and imperial power augments the normalization of whiteness, largely because colonial systems had to justify the subjugation of non-white natives because of inferiority that became attached to racial difference. In the past, representations of non-whites and whites, created by white people, are likely to cast people of European descent as superior to their nonWestern counterparts. Infantilizing people of color, portraying them in positions of servitude, and ridiculing their cultures and habits were common strategies. The underlying impetus of non-white inferiority and white superiority has survived in contemporary representations, despite a rising awareness of derogatory im- 
ages. Although crass racial and ethnic caricature are seldom widely publicized, especially in contemporary advertising campaigns, the habitual usage of exotic landscapes, sometimes including native people, sometimes not, conveys a world view of imperial and colonial paradigms about racial inferiority and difference.

\section{Consumption of Leisure and Luxury: Chocolate, Coffee, and Tea}

Contemporary consumer culture often evokes an imagery of untouched, pristine landscapes for products that originate in non-Western locations. These items such as tea, coffee, and chocolate are often associated with nature's richness and tropical delights. The history of origin of the products and their introduction to Western markets are of course strongly linked with the course of colonial trades, especially those of the transatlantic slave trade, and thus with mechanisms of racialization and racial disenfranchisement. Franchises such as Starbucks Coffee have specialized in catering to the pleasure of consuming coffee and tea and offer a large variety of pricy coffee products. An image of a large elephant for Starbuck's popular coffee brand "Kenya", for example, dominates the brand's logo. The automatic connotation of Kenya, a Central African state, with the animal world, and its automatic implication of primitivism and inferiority to European civilizations, stems from the legacy of the colonial encounter and the production of visual imagery of Africa during the eighteenth and nineteenth century.

Products such as tea, coffee, and chocolate have always had an exotic value to people on the European continent and in North America, mainly because the raw materials for any of these products cannot be grown solely in neither of those continents. The discovery of all three items falls during the period of colonial expansion on the African, Asian and South American continents. Chocolate, for example, depends on the growing, harvesting, and roasting of cocoa beans that grow on cocoa trees, with the Latin name Theobroma Cacao. The plant is native to South and Central America, and Spanish colonists, who "discovered" South America, are usually accredited with the introduction of cocoa to Europe. Hernan Cortes' excursions to the Americas under the protection and finance of the Spanish crown brought the delightful pleasure of cocoa, and later on chocolate consumption first to the aristocracy and subsequently to the wealthy bourgeois in a variety of places. Technological innovations enabled the mass production of both cocoa and chocolate, which, by the early twentieth century, became regular products in many European households. Tea originated on the Asian continent, most notably in part of present-day China and Japan. The tea plant, under its Latin name Camellia sinensis thrives best in tropical and subtropical climates. Tea 
seemed to have made its way to European society during the 16th century and led to a spread of tea plantations under European colonial rule, most notably the British throughout Asia, including India and China. Coffee is the third of these products referenced in this article. There are two main species of the coffee plant, Coffea arabica and Coffea canephora. The drink brewed from the plants' roasted seeds was brought to Europe via North African and Arabic cultures during the 17th century, where it was a popular beverage before its introduction in Europe.

There is an implicit association of luxurious indulgence evoked by the consumption of chocolate, coffee, and tea that runs deep in Western cultures. Coffee breaks, tea time, and snacking on a piece of chocolate often serve as brief escapes from strenuous and demanding twenty first century lifestyles. The food and beverage industry uses ideas of indulgence and treating oneself as recurring tropes in its advertising for any of these items. In addition to these themes, exoticized imagery of tropical and subtropical locations that, in a Western context are exoticized, contribute to the fantasy world that some of the advertising strategies create for their consumers. What often falls under the table, however, is the fact that the idealized version of the colonial world and it exotic landscapes obliterates the existence of complicated networks of power relationships that would disturb the peaceful and serene quality of the fantasy world. Further, the historical legacy of colonialism is made invisible by an apparent celebration of these "wonderful" places. Contemporary Western visual depictions of colonial or imperial worlds build on the various illustrations and paintings by artists who traveled to the colonies, of ten hired to document the natural riches of the natural landscapes. Beginning in the 16th and 17th centuries, illustrations of exotic flora and fauna became standard themes in paintings, illustrations, and on other genres of decorative arts such as porcelain, embroidery, and domestic art work continuing to gain in popularity throughout eighteenth and nineteenth century Western societies. Despite their scientific desire to accurately portray the natural environments, these images are suffused with the cultural and social etiquettes and ideologies of their time. As many of these botanical studies depicted plants not native to Europe, the images are permeated with the gaze of imperialism. By the late nineteenth century, images with botanical elements had long entered not only the realm of artistic production, but also made their entrance to consumer culture.

\section{Portable Colonial Aesthetics: Nineteenth Century Trade Cards}

Advertising media in the nineteenth century utilized the visual inventory established by artists and scientists of the previous decades to promote products that bore connections with exotic landscapes, drawing on the common tropes 
identified as "imperial kitsch" and "tropical plenty": "In people's minds, however, chocolate remained entrenched in its colonial and precolonial origins, signifying the tropics, exoticism, and even sex appeal - all characteristics highlighted and mythologized by nineteenth-century American advertisers." Trade cards were one form of advertising media that benefited from the appeal of visual imagery and utilized the power of the visual world to market products. They drew on widely circulated and established forms of portraying foreign and exotic landscapes as well as populations. Foreign and exotic cultures had been accessible to late nineteenth century Europeans and North Americans through World Fair's, circus shows like P.T. Barnum's shows in the United States or Hagenbecksche Voelkerschauen in Germany, and, among others, book, newspaper, and magazine illustrations. Advertising ephemera were part of a larger visual and material culture of portraying "otherness." Products such as coffee or cocoa, which were native to non-Western locations, almost always territories under colonial or imperial rule, drew on standard imagery of exotic and foreign people, landscapes, and objects associated with these cultures abroad.

Trade or advertising cards were a common and wide-spread form of advertising in the nineteenth century. The advances in printing technology and especially the development of chromolithography enabled the wide distribution of trade cards in the United States as well as in other parts of the Western world, such as England, France, and Germany. Motifs ranging from flowers and children to interior designs and specific products such as iron stoves were displayed on these cards that would usually come in a rectangular shape measuring approximately $5 \times 8$ inches. Racial and ethnic stereotypes as well as national and patriotic motifs were also very popular. Produced in an era of imperialism and colonization, trade cards represent an interesting and often understudied source to shed light on the formation of ethnic and racialized identities in the late nineteenth century and their legacy for contemporary questions and paradigm in Ethnic Studies and related fields. Their wide distribution among a large variety of people from different social and cultural background make them into fascinating and revealing windows to gain insight about cultural ideologies and social structures of the late nineteenth century.

An example of such a depiction of "tropical plenty" is the trade card by the London based company Taylor Brothers for its product Maravilla cocoa. By showing a comprehensive process of the entire production process, from cultivation to industrial production, this card stresses the achievements of Western cultures. The main part of the card is occupied by an illustration of two cocoa pods, the fruit of the cocoa tree, placed in a tropical landscape with a small mill in the background, placing the product in the cultural context of its place of origin. The card does not provide specific information about the exact location of this 
floral landscape; the natural environment, however, suggests that this plantation is located in the West Indies, considering England's large number of colonies in that area and the cultivation of cocoa from places like Trinidad. The smaller image on the very top of this card shows the London factory of the Taylor Brothers company. The "natural" and exotic landscape, which takes up more than half of the card's space, is juxtaposed with the smaller display of the factory in England. Despite the smaller size, the placement of the London factory on the very top of the card, a place where the viewer's sight is automatically drawn, dominates the card, despite the fact that the natural landscape of the cultivation site covers more space on the card.

The composition of the card suggests a teleological reading of the product's creation, from the raw produce to the refined consumer product, that establishes the economic and, in extension, cultural superiority of industrialized cultures over its overseas colonies and territories. Starting with the cocoa fruit in its natural state on the bottom, a path leads through the natural landscape of cocoa trees toward the manufacturing building, a mill operated by water power, as the large wheel on the right side of the building suggests. Two native workers are placed in front of it, suggesting that the building in the back indeed is the main house of the cocoa plantation. The actual path becomes a metaphorical route, leading in extension the top of the card symbolizing the superior environment of Western industrialization represented here by the Taylor Brothers Mills in London, England, which does not longer operate with water-power as the more primitive mill on the actual plantation. The smoking chimneys of the British factory mark the triumph of the industrialized West over the archaic indigenous and natural landscapes of its colonies. The display of industrial landscapes such as this factory was a common trope for many manufacturers in the late nineteenth century. The business world was eager to demonstrate its modernist methods of mass production and ensure its consumers of its success. By visual differentiation with the site of cultivation, where the raw product, the cocoa plant, dominates the view on the very bottom of the card, the site of industrial production, on the top on the card and placed in an oval frame, emerges as the superior place of economic, cultural and social lifestyle.

In addition to the portrayal of natural landscapes, almost untouched by Western industrial improvements, nineteenth century trade cards also depicted scenes in which the consumer could inscribe her- or himself more actively into the portrayed scenery and partake, by projection, in the opulent and luxurious lifestyle and especially conumption of food made possible by colonialism. The trade card for Noix de Coco, dating from approximately the same time period than the Taylor Brothers advertisement card, does not stress the connection to the industrialized West, but, rather, represents a landscape of luxurious indulgence 
in an exoticized framework, depicting McClintock's category of "imperial kitsch". Its motif is reminiscent of the illustration in Waller's travel narrative

This trade card presents several interesting elements typical for landscapes of Western colonial fantasies. The division of labor between members of the ruling class and the indigenous inhabitants of colonized territories, the gendered landscape of consumption, and the reference to of a larger market structure outside the portrayed setting are important aspects of this image. By arranging different elements in the image representing consumption and production, the card ultimately stresses the aspect of consumption by inviting the consumer to imagine herself as the leisurely consumer who enjoys the attention of her servants. Where the focus in the Taylor Brothers card was on production and industrial processes to stress Western superiority, the main narrative of this advertising card suggests an environment of leisure and indulgence enabled by the use of Noix de Coco only accessible to whites. Non-whites, in this image, only exist to help create the atmosphere of luxury and comfort for the white consumer. All three servants in this picture contribute to the white woman's pleasure, either by fanning her, serving her, or laboring to create the product that contributes to the fantasy world of exotic comfort. The lower half of the card references a simplified production cycle of the product, represented by the native worker and the boxes toward his left. The young male sorting through a bucket of coconuts can be read as a reference to the actual labor of harvesting the raw product that is needed to produce Noix de Coco. His labor, however, is in direct connection with consumption of the product, since his location at the feet of the reclining woman links him with her, the consumer, who occupies the center of the picture. Next to him, boxes that seem to contain the finished product are located in the lower left corner of the picture. A coconut is placed on top of these boxes to draw attention to the fact that these boxes, which seem to be ready for shipment, contain the product advertised. The tray of products that are served by a native female servant to the white woman in the hammock is right next to the boxes. The proximity of the boxes and the serving platter suggest that Noix de Coco, the content of these boxes, was used to prepare to these delicious treats, which the reclining white female is indulging in. The production cycle of the product, from right through left on the bottom half of the card, is linked with consumption of the product. Again, native non-white labor generates products that establish a landscape of leisure and consumption confirming the superiority of Western lifestyles.

Both cards draw on depictions of "tropical plenty" and "imperial kitsch. They share visual strategies that support the general belief of Western cultural superiority, firmly establishing whiteness as the cultural norm. On both cards, the natural landscapes of the non-Western, colonized sceneries are full of plants. On the Noix de Coco trade card, exotic animals are added to enhance the foreign 
quality of the environment. The closeness of non-Western cultures to a more "natural" environment excludes them from the more civilized spheres of Western nation-states. Westerners had conquered nature, as is suggested by the factory on the Taylor Brothers trade cards, and asserted themselves into their surroundings, non-Westerners had not. For Western cultures, natural and pristine landscapes became places that could be used for resources to enable mass production. Conquests of untamed environments were an implicit part of civilized societies, which seemed to offer a more refined lifestyle. Because the reclining white woman represents Western cultures that have successfully tamed wild landscapes and subordinated non-whites, she is able to indulge in leisurely consumption. The marginalization of people of color, who represent the workforce, is enhanced not only but their depiction of servants of farm workers (as in the background on the Taylor Brothers trade card), but also by the assertions of Western civilization in both depictions.

The Taylor Brothers card symbolizes civilized conquest over nature with its representation of the London factory, whereas on the Noix de Coco card, several elements in the surroundings, such as the Greek statue and the water fountain in the background, attest to the present of Western civilization. Ultimately, the creation of exotic landscapes full of luxury and leisure fail to portray the actual labor needed in the production process of both cocoa and Noix de Coco. Both images disguise the dependency on non-Western labor and resources to enable Western superiority by drawing attention to the natural and primitive landscape of non-Western environments.

\section{Plantation Chocolate}

The depiction of plantation life in the tropics or subtropics, which was so predominantly displayed on the late nineteenth century trade card for Maravilla coffee, reappears on a brand of chocolate in Germany almost more than a century later. In 2000, the renowned chocolate manufacturer Rausch developed a new product of mass-marketed chocolate. The company launched a series of different chocolate brands named after the place of origin of its cocoa beans. Each individual kind of this series is different from the other in its cocoa content. All kinds, however, are wrapped in the same packaging (picture 4). Each chocolate brand of the eight kinds that are available is named after a different location, depending where the cocoa seeds used for this particular brand are grown. Despite the different names, the image of the plantation scene appears on every wrapper. It seems to serve as an imaginary place that can be applied to each of these locations, although the location that served as the model for the original picture might have been neither of these places. The nostalgia involved in the plantation scenery 
might also serve as a reminder of Rausch's century-long tradition as a chocolatier. In 1890, Wilhelm Rausch, senior, opens his first pastry shop in the Rhineland. In 1918, his son, Wilhelm Rausch, junior, expands the family business and opens the company Wilhelm Rausch in Berlin. In 1999, a year before launching the successful brand of Rausch's plantation chocolate, the company merges with another well-known chocolate business and establishes the Schokoladenhaus Fassbender \& Rausch am Gendarmenmarkt (House of Chocolate by Fassbender \& Rausch on the Gendarmenmarkt) in Berlin. The store, with an adjacent restaurant that specializes in chocolate dishes, carries a larger, colored reproduction of the plantation scene displayed on each wrapping.

Each plantation chocolate package, aside of different sizes, includes the copy of the nostalgic plantation illustration or painting on it. On the "original" image, displayed in the Berlin store, the inscription Theobroma Cacao, L., the Latin name for the cocoa plant, is printed on the upper margin of the framed picture . The plantation landscape - yet another example of sceneries of "tropical plenty" - between the two different depictions of the cocoa plant seems to portray a cocoa plantation. A number of laborers are represented on the image: a worker in front of the plantation in the background, a woman, accompanied by a small child, who balances a full basket on her head, and other workers harvesting cocoa tress on both sides of the image. The curving road leads from the left corner of the image to wards its destination in front of the plantation house, past an orchard of cocoa trees. The entire scene describes the cycle of cocoa planting, the main ingredient for Rausch's plantation chocolates. The abundant natural landscape suggests a pristine environment largely removed from the contemporary production of cocoa. The selection of this scene for the company's plantation chocolate seems to be motivated to place the product into the century-long tradition of chocolate and cocoa production. However, this context of nostalgia also, similar to the trade cards in the late nineteenth century, stirs up Western colonial aesthetics that are saturated with stereotypes of non-Western primitive and archaic themes.

Rausch's practice of colonial nostalgia does not stop with the plantation image that gives the product its name. In addition to this ubiquitous image, other visual representations are used that link the chocolate product to their countries of origin and, as I suggest, to a colonial imaginary that is so central to the marketing of these products and others of its kind. On the backside of the package wrappers of each specific brand, a map highlights the location in which the cocoa seeds used for the specific kind of chocolate are grown (picture 4). Areas north of the Tropic of Cancer are left out. The image is divided into half by a discontinuous line that represents the equator. On the Madagaskar chocolate wrapper, a red dot points out the location of the cocoa plantation, accompanied by the location (and chocolate brand) name and an image of a cocoa fruit. This map becomes a repeti- 
tive image in the company's packaging design. It is also used as a sticker sealing a wooden cigar-like box that contains twelve chocolate sticks from four different plantation chocolate brands. Contrary to the map reproduced on the back of each chocolate bar, this map includes all eight plantation locations. Further, this map is also painted as a mural on one of the walls at the Rausch-Fassbender store in Berlin. None of these maps includes Europe or Germany, where the final product is actually produced. The Rausch Company owns an extensive chocolate factory in Peine, Germany, where, most likely, the majority of the merchandise is created. The imaginary connection to tropical and exotic places seems obvious when marketing for products based on raw materials grown in these areas. However, it is undeniable that the visual imagery (the historical plantation illustration and the map) that is utilized to market these products is deeply rooted in a colonial aesthetic that, uncritically consumed, stands the chance of replicating Western assumptions and stereotypes about these locations.

The use of maps as marketing tools for products based on raw materials that are native to the tropical and subtropical regions of the world, such as cocoabased products, seems to be a common strategy. A coffee cup used at a coffee vending machine at a autobahn ("highway") rest-stop serves as another example. Although this map includes the Northern Hemisphere, the proportions of the different continents seem skewed. Similar to the map on Rausch plantation chocolates, this map highlights seven locations where coffee is grown, such as Mexico, Columbia, Brazil, Ivory Coast, Kenya, Indonesia, and the Philippines. Each name is accompanied with an image of a coffee bean, not unlike the Rausch map of cocoa plantations. Again, this map, despite its inclusion of the continents north of the Tropic of Cancer, highlights countries located in tropical and sub-tropical regions. All of the countries named on this map were, at one time or another, subjugated to the colonial rule of one or more European nations. Thus, both maps, one specifying cocoa plantations, one coffee plantations, serve as visual reminders of European colonialist expansion and imperialist politics that have shaped global economic structures to the present.

\section{Sarotti Chocolate}

Other chocolate companies have also started to emphasize the tropical origins of their chocolate products. Sarotti chocolate, a traditional German chocolate manufacturer, now in the hands of a French-Swiss company, introduced a new brand of fine chocolate, more affordable than the much more selectively produced items sold in specialty stores. Similar to Rausch's plantation chocolate, the names of the five variations designate the locations of the cocoa seeds used to manufacture these products: Java, Ecuador, Papau-Neuguinea, St. Thome, and 
Santo Domingo. Contrary to Rausch plantation chocolate, the visual design of the Sarotti products are minimalist and focus on the printed logo and an actual image of the product on the bottom half instead of evoking a nostalgic exoticism. However, the text on the back of Sarotti's Santo Domingo brand suggests the natural riches and exotic delights of the Caribbean island: "The Caribbean climate gives the Santo Domingo cocoa bean a gentle and mysterious taste, while the influence of the Atlantic Ocean underscores the sturdy and wholehearted nuances of the Santo Domingo cocoa." The text positions the city of Santo Domingo on the island Hispaniola, which today is divided into Haiti on its Western part and the Dominican Republic on its Eastern part, as the meeting point of the Caribbean Sea and the Atlantic Ocean.

These two places serve as metaphors for the New World's indigenous and slave cultures and the Old World's European civilizations, respectively. The Caribbean environment, according to the description, supplies the "gentle" and "mysterious" qualities of the product, whereas the Atlantic Ocean, and its connections to the Old World of European cultures, brings out the "sturdy" and more wholesome ("wholehearted") characteristics of the product. This cocoa bean seems to be the perfect hybrid of the colonial encounter that has shaped the history of the island and has affected its economic, social, and political conditions to this day. This text subtly inscribes the "soft," almost feminine qualities of gentleness and mysteriousness traditionally associated with simplistic ideas of exotic landscapes and their cultures with the Caribbean and assigns more masculine attributes to the Atlantic Ocean and its closer proximity to European civilization. This juxtaposition repeats the blueprint of colonial imagination that informs Western perceptions of former colonized locations. Unconsciously, this description by Sarotti in combination with the visual materials used by Rausch plantation chocolate insinuate a colonial and imperialist aesthetic that is often accountable for cultural differentiations of "us" versus "them" that lies at the core of racially infused cultural and economic politics.

The strategy of differentiating between refined European or Europeanbased cultures and wild and untamed colonial settings is a recurring motif in Sarotti's advertising strategies. Approximately a century before, the company Sarotti, with its then headquarters in Berlin, issued a trade card series consisting of six different cards. This series drew on images that established clear lines between "us" and "them." These cards were mostly placed in chocolate packages that could be purchased in vending machines. The chocolate manufacturer Stollwerck in Cologne, one of Sarotti's competitors, is often credited for the innovative and extensive use of these sammelbilder ("collector's cards") or advertising cards. These trade card series, often with accompanying albums, started appearing in the late nineteenth century. As the twentieth century progressed, the albums' 
themes and pictorial works grew more and more sophisticated.

Stollwerck published one of its first cards series with accompanying album in 1898. From year to year, the production of these paper ephemera grew more and ore sophisticated. By the early 1900s, the albums were not only used to collect individual series of cards that usually consisted of six single cards. Albums with overarching themes such as Das neunzehnte Jahrhundert ("the nineteenth century") from 1902/03 or Helden-Album ("album of heroes"), from 1908/09, were designed to assemble card series that could consist of up to100 cards or more. Sarotti issued a card series call Die Siegesalle ("Avenue of Victory") in the early twentieth century.

Stollwerck, Sarotti and other companies issued trade card series that were meant to educate its consumers, mostly children, about their own culture and history, but also about different cultures and nations. Often, cards dedicated to displaying non-European people drew on distinguishing their subjects from the "civilized" worlds of the consumers. The six-card series by Sarotti mentioned above illustrates this poignantly. The series is entitled Kriegsfuehrung bei wilden Voelkern ("warfare among the wild people"). Each card represents a different population, accompanied by a written explanation of each motif on the back of the card. All six population groups are of non-European origin. Picturing and describing population groups outside of European cultural heritage as "wild" and keen on warfare impressed a clear us-versus-them understanding of global communities that are continued, albeit more implicitly, in contemporary consumer culture. These illustrations supported Western cultures' overall belief in the moral inferiority and inadequacy of non-Western communities, which in turn provided the West with a foundation to celebrate its dominance and justify the necessity of controlling people of color.

\section{Conclusion: Colonial Aesthetics and Contemporary Art}

Unexamined colonial aesthetics that repeat the racialized imagery of "imperial kitsch" and "tropical plenty," can, often unwillingly, perpetuate racial hierarchies that cast non-whites in positions of cultural dependence and primitivism and project whiteness as the norm. Photographer and Multimedia artist Gregory Colbert's recent work is a good example. Colbert is a very well-known photpgrapher from Canada whose recent show "Ashes and Snow" has received a lot of critical acclaim. The interactive exhibition includes Colbert's photographs, a one-hour film and several shorter films, installations, and a letter-novel written by Colbert. It originated in Venice in 2002 and has since then traveled as a "Nomadic Museum" to New York in 2005 and Santa Monica, California, in 2006. His black-and-white pictures portray animals and humans in unusual situations and 
in close proximity to each others. The artwork that is part of "Ashes and Snow" originated during Colbert's travel to thirty-four different countries over the past fourteen years, among them Kenya, Borneo, and Tonga. Colbert's philosophy is to show the animals in their natural habitat in harmony with human beings. His philosophy is to bring humanity closer to nature, a relationship that, he claims, we have lost. Colbert creates fantastic landscapes that show humans and animals in harmony with each other, but his well-intentioned project generated a variety of criticism.

On an internet blog called "Listening for Change", a number of individuals expressed their uneasiness with the show, especially the fact that not one human being shown with an animal in any of the pictures or films seemed to be a person of European descent. Women, men, and children of color, from various parts of the world, are the human subjects of Colbert's artistic photographs and film material. In the exhibit, the visual material is accompanied by a number of fictional letters written to his wife by a man who traveled the world on a year-long journey. The text stress a desire for harmony and peace between different species of the world and an overall yearning to develop a closer and more authentic relationship to nature. Colbert himself is keen about the exhibit's desired effects on its viewers to carry a message about peacefulness and harmony: "In exploring the shared language and poetic sensibilities of all animals, I am working towards rediscovering the common ground that once existed when people lived in harmony with animals. The images depict a world that is without beginning or end, here or there, past or present." Colbert's desire for the a-historic nature of his project, however, raises deep concerns about the actual history behind colonial encounters and resulting power relationships not so much between humans and animals, but between the humans shown in Colbert's artwork, people of color, and the ones absent from it, white people.

Colbert's work exemplifies the complicated racialized politics of representations. His pictures seem to re-inscribe whiteness by utilizing centuries-old visual traditions of representing exotic panoramas, animal, and human beings. Colbert's artwork as well as other objects of everyday life's material world are carriers of the historical legacies of colonial encounters. Consumer culture is no exception. The iconography of "imperial primitivism" in patent medicine and in material culture around sugar and confectionary in nineteenth century U.S. culture have persisted into the twenty first century, re-designing eighteenth and nineteenth century iconography of "tropical plenty" and "imperial kitsch." The study of popular culture, especially of visual and material culture, deserves a central place in critical inquiries about the processes of racialization, the interdependence of racialized categories such as blackness and whiteness, and the manifestations of racial privilege and oppression in social and cultural structures. 
Contemporary imagery in popular culture has continued the representational practices of colonial and imperial aesthetics that are based on racially exclusionary structures, placing the racialized construction of whiteness on top of social and cultural hierarchies. The continuous use of "imperial kitsch" and imagery of "tropical plenty" in areas of popular culture other than consumer culture can serve as prospective case studies for Ethnic Studies and Whiteness Studies alike.

Research for this article was made possible by generous fellowships at the National Museum of American History and the Winterthur Museum and Country Estate. Valuable suggestions about eighteenth century aesthetics were provided by my colleagues at Winterthur Eric Gollanek and Anna Marley. My appreciation also goes to Cate Cooney, head librarian of rare books at Winterthur, who has extended her assistance to me. Finally, the kind support of Dr. Christian Hillen at the RWWA in Cologne made this article possible.

1. Tyler Stallings, ed., Whiteness: A Wayward Construction (Laguna Beach, CA: Laguna Art Museum, 2003; David Roediger, ed., Black on White: Black Writers on What it Means to be White, (Schocke, 1999); Matthew Frye Jacobson, Whiteness of a Different Color: European Immigrants and the Alchemy of Race (Cambridge, MA: Harvard University Press, 1998); George Lipsitz, The Possessive Investment in Whiteness: How White People Profit from Identity Politics (Philadelphia: Temple University Press, 1998); Richard Delgado, ed., Critical White Studies: Looking Behind the Mirror, (Philadelphia: Temple University Press, 1997); Ruth Frankenberg, ed., Displacing Whiteness: Essays in Cultural Criticism, (Durham, NC: Duke University Press, 1997); David Roediger, The Wages of Whiteness: Race and the Making of the American Working Class (London: Verso, 1991).

2. I will use the term Whiteness Studies during the article, but this term refers to all the various fields called Critical White Studies, Critical Whiteness Studies, and so on.

3. Johnella Butler, ed. From Color-Line to Borderlands: The Matrix of American Studies (Seattle: University of Washington Press, 2001): xxi.

4. Michelle Habell-Pallan and Mary Romero, eds., Latino/a Popular Culture (New York: New York University Press, 2002).

5. Richard Dyer, White (London: Routledge, 1997): xiii.

6. Jan Nederveen Pieterse, White on Black: Images of Africa and Blacks in Western Popular Culture (New Haven: Yale University Press, 1992), 10. 7. Anne McClintock, Imperial Leather: Race, Gender and Sexuality in the Colonial Context (New York: Routledge, 1995): 209. 
8. Henry Nelson Coleridge. Six Months in the West Indies. 3rd ed. (London: John Murray, 1825): 149.

9. John Michael Vlach.. The Planter's Prospect: Privilege and Slavery in Plantation Painting.( Chapel Hill, NC: University of North Carolina Press2002); lan Gregory Strachan. Paradise and Plantation: Tourism and Culture in the Anglophone Caribbean (Charlottesville, VA: University of Virginia Press, 2002). 10. Wendy A. Woloson. Refined Tastes: Sugar, Confectionery, and Consumers in Nineteenth-Century America (Baltimore: Johns Hopkins Press, 2002).

11. John Augustine Waller. A Voyage in the West Indies: containing various observations made during a residence in Barbados, and several of the leeward islands (London: Sir Richard Phillips, 1820).

12. Pieterse, White on Black, 90.

13. Ibid., 91.

14. The Starbucks website lists the company's vast selection of coffees in the coffee menu, www.starbucks.com, accessed September 15, 2006.

15. Tim Barringer, "Imperial Visions: Responses to India and Africa in Victorian Art and Design," in The Victorian Vision: Inventing New Britain, ed. John MacKenzie (London: V\&A Publications, 2001): 315333.

16. Sophie D. Coe and Michael D. Coe, The True History of Chocolate (New York: Thames and Hudson, 1996).

17. Alan Macfarlane and Iris Macfarlane, The Empire of Tea: The remarkable History of the Plant that took over the World (Woodstock, NY: Overlook Press, 2004).

18. Antony Wild, Coffee: A Dark History (New York: W.W. Norton, 2005).

19. Harriet Ritvo, "The Natural World," in The Victorian Vision.

20. Beth Fawkes Tobin, Colonizing Nature: The Tropics in British Arts and Letters (Philadelphia: University of Pennsylvania Press, 2005): 24; , Michael Gaudio, "Swallowing the Evidence: William Bartram and the Limits of Enlightenment," Winterthur Portfolio 36, 1 (Spring 2001): 1-17.

21. Woloson, Refined Tastes, 116.

22. Hans-Peter Beyerhoeffer and Eckhart Hellmuth, eds., Exotica: Konsum und Inszenierung des Fremden im 19. Jahrhundert (Muenster: Lit Verlag, 2003).

23. Robert Jay, The Trade Card in Nineteenth-Century America

(Columbia, Miss: University of Missouri Press, 1987).

24. Marilyn Maness Mehassy, “Advertising Race/Raceing Advertising: The Feminine Consumer(-Nation), 1876-1900," Signs 23, 1 (Autumn 1997): 131-174. 25. The exact date of this trade, as those of most paper ephemera, is difficult to identify. Most likely, this card was printed during the 1880s, probably not later than the mid 1890s and not earlier than 1876, the year of the Centennial Exhibition in Philadelphia that marked the explosion of advertising cards on the 


\section{U.S. consumer markets.}

26. Jackson T. Lears, Fables of Abundance: A Cultural History of Advertising in America (New York: Harper Collins, 1994).

27. Psyche Williams-Forson, Building Houses out of Chicken Legs: Black Women, Food, and Power (Chapel Hill, NC: University of North Carolina, 2006); Sherrie A. Inness, Kitchen Culture in American: Popular Representations of Food, Gender, and Race (Philadelphia: University of Pennsylvania, 2001);

M.M. Manring, Slave in a Box: The Strange Career of Aunt Jemima (Charlottesville, VA: University of Virginia Press, 1998).

28. The card advertised a baking supplement based a coconut extract that could be used, as the card announce, for "puddings, pies and pastry." Noix de Coco is the French expression for coconut. Warner \& Merrit trade card, Philadelphia, late nineteenth century, Warshaw Collection. The trade card probably dates between 1876 and 1893. The trade card business in the US exploded after the World Expo in Philadelphia, continued to be very popular throughout the 1880s, and, by 1893, the Chicago World Expo, started disappearing.

29. The history of the company as well as the most current product information can be found on the company's webpage, http://www.rausch-schokolade.de, accessed September 15, 2006.

30. The illustration on the wrapper turns out to be a section of a framed picture that is on display in Rausch's Berlin store (see picture 5). The origin of this picture is, at this point, unknown. Contacting the company's headquarter has been unsuccessful. Judging from the composition of the image, it seems as if the particular scene is part of a larger creation. The illustrations of the plants on the upper left and right corners seems cut-off, and the framing of the landscape scenery dominating the picture give the impression as if the illustration actually continued beyond the borders of its frame. Based on the drawing on the cocoa plant, this image might be part of a larger work on exotic plants. The image seems inspired by botanical drawings of exotic plants from the eighteenth and nineteenth centuries as well as by illustrative accounts of plantation life in the colonies.

31. The eight brands of Rausch plantation chocolate are differentiated by the percentage of cocoa used in each individual brand: Noumea (New Guinea), 39\%, Java (Indonesia), 37\%, Madagaskar (Madascar), 39\%, Puerto Cabello (Venezuela), 43\%, Amazonas (most likely Brazil), 60\%, Arriba (Ecudaor), 70\%, Tobago, 75\%, Trinitario (Trinidad), 80\%. The wrapper in my collection date from 2004. At that time, Madagaskar chocolate was one of the milk chocolate products without any specification of its cocoa content. The other wrapper in my collection, Santo Domingo, is not manufactured anymore.

32. The chocolate business established by Heinrich Fassbender in 1863, which 
grew to a business with a number of production sites in the twentieth century, specialized in the production of fine filled chocolate and chocolate truffles, which quickly earned him the status of royal supplier.

33. The label of each chocolate product states that it was produced in Germany ("Made in Germany"), although it is left unclear as to which factory manufactures the final product.

34. It is unclear why these seven locations were chosen and others, such as Ethiopia and Costa Rica, also two well-know coffee producers, are left out. 35. My translation of the German text on the packages backside comes from a package purchased in Muenster, Germany, in April 2006: "Das karibische Klima verleiht de Santo Domingo Kakaobohne eine sanfte und geheimnisvolle Geschmacksnote, waehrend die Einfluesses des atlantischen Ozeans die kraeftigen und vollmundigen nuancen des Santo Domingo Kakaos untermalen." 36. See Brent Hopkins, "Human-Animal Connection: Unusual Exhibit opens in Santa Monica Today," The Daily News of Los Angeles January 14, 2006; Dani Katz, You say Lemur, I say Tapir," LA Weekly January 20, 2006; Jim Regan, "More than just a Photo Portfolio," Christian Science Monitor March 8, 2006. 37. The discussion is posted on the blog "Listening for Change: Ending Racism and Classism through Closeness" on the webpage www.blogspot.com.

38. This quote appears on Colbert's sophisticated and innovative webpage http://www.ashesandsnow.org. It opens the brief narrative on the project's vision.

39. Woloson, Refined Tastes: 134. 